\title{
GROWTH OF Pinus glabra IN SOUTHERN BRAZIL
}

\author{
Mário Dobner Jr. ${ }^{1 *}$, Marcos F. Nicoletti ${ }^{2}$, Nilton S. Novack Jr. ${ }^{3}$, Glaucia C. Nunes ${ }^{4}$ \\ ${ }^{1 *}$ Federal University of Santa Catarina, Department of Agriculture, Biodiversity and Forests, Curitibanos, SC, Brazil - \\ mario.dobner@ufsc.br (*AUTHOR FOR CORRESPONDENCE) \\ ${ }^{2}$ State University of Santa Catarina, Department of Forest Engineering, Lages, SC, Brazil - marcos.nicoletti@udesc.br \\ ${ }^{3}$ Florestal Gateados Ltda, Campo Belo do Sul, SC, Brazil - nilton@ gateados.com.br \\ ${ }^{4}$ Federal University of Santa Catarina, Curitibanos, SC, Brazil - glauciacota@ gmail.com \\ Recebido para publicação: 23/01/2018 - Aceito para publicação: 01/08/2018
}

\begin{abstract}
Species of the genus Pinus are widely cultivated in Brazil, in the south of the country, mainly P. taeda and $P$. elliottii are responsible for suppling for diverse industrial segments. Although poorly studied, other species from the same region of natural distribution could also possibly present good growth potential. The aim of the present study was to evaluate the development of different dendrometric characteristics of provenances of $P$. glabra grown in the highlands of south Brazil during 24 years of growth. The values obtained for $P$. glabra in the studied region was compared with the ones from its natural distribution region and with data of $P$. taeda in south Brazil. By means of annual dendrometric measurements during almost the entire studied period, especially at age 24 years, the growth and productivity of the species was addressed. All studied provenances shown suitability to the evaluated edaphoclimatic conditions, with initial height growth above $1 \mathrm{~m}_{\text {year }}{ }^{-1}$ during the first 5 years. Productivities above $30 \mathrm{~m}^{3} \mathrm{ha}^{-1}$ year $^{-1}$ at age 24 years, as well as the production of dominant individuals with $30 \mathrm{~cm}$ of dbh at age 15 years can be expected. Therefore, the potential for commercial use of P. glabra in the highlands of south Brazil was proven, thus being an interesting alternative to the commonly used species.
\end{abstract}

Keywords: Alternative species; Forest Management; Multiple use of the wood.

\section{Resumo}

Crescimento de Pinus glabra no sul do Brasil. Espécies do gênero Pinus são amplamente cultivadas no Brasil. No sul do país principalmente $P$. taeda e $P$. elliottii são responsáveis pelo abastecimento de diversos segmentos industriais. Apesar de pouco estudadas, outras espécies, oriundas da mesma região de ocorrência natural das primeiras, poderiam apresentar bom potencial de crescimento. O objetivo do presente estudo foi avaliar o desenvolvimento de diferentes características dendrométricas de procedências de $P$. glabra no planalto sul do Brasil ao longo de 24 anos de cultivo. Os valores quantificados para $P$. glabra foram comparados com dados da mesma espécie em sua região de ocorrência natural e com dados de $P$. taeda no sul do Brasil. A partir de medições dendrométricas anuais durante boa parte do período de estudo e de uma medição realizada aos 24 anos de idade, o crescimento e a produtividade da espécie foram determinados. Todas as procedências testadas se demonstraram aptas ao cultivo nas condições de estudo, com crescimentos iniciais em altura superiores a 1 $\mathrm{m}$ ano $^{-1}$ nos primeiros 5 anos, indicando boa adaptação às condições edafoclimáticas avaliadas. Produtividades acima de $30 \mathrm{~m}^{3} \mathrm{ha}^{-1}$ ano $^{-1}$ aos 24 anos de idade, bem como a produção de indivíduos dominantes com $30 \mathrm{~cm}$ de diâmetro aos 15 anos de idade podem ser esperados. Desta forma, comprovou-se o potencial para uso comercial de P. glabra no planalto sul do Brasil sendo, portanto, uma alternativa interessante às espécies comumente utilizadas.

Palavras-chave: Espécies alternativas; Manejo Florestal; Uso múltiplo da madeira.

\section{INTRODUCTION}

Numerous species of the genus Pinus were introduced in Brazil. In the southern plateau of the country, $P$. taeda and $P$. elliottii stand out due to the adaptation to edaphoclimatic regional characteristics and consequently high increment in volume (SHIMIZU; SEBBENN, 2008). These two species have an established silviculture and are used as raw material in several industrial processes (IBÁ, 2017).

Pinus glabra Walt, or Spruce pine in the English language (CODER, 2016), is not a widespread species in southern Brazil and even in experimental plantations it is rare. Together with P. taeda and P. elliottii, it belongs

FLORESTA, Curitiba, PR, v. 49, n. 2, p. 277-286, abr/jun 2019. 
to the group of species known as 'Southern Pines' from the United States, because of the natural distribution in that country from the coast of South Carolina and north from Florida to Louisiana (MIROV, 1967; LITTLE Jr., 1971).

In its region of origin, P. glabra is a minor species in relation to the other 'Southern Pines' (Pinus taeda L., Pinus echinata Mill., Pinus elliottii Engelm and Pinus palustris L.) (GULDIN, 2011). It grows on acid soils, poorly drained, sandy and rich in organic matter. The region of natural occurrence has annual precipitation of 1,300 $\mathrm{mm}$ well distributed throughout the year, and an average annual temperature of $16{ }^{\circ} \mathrm{C}$ (BURNS; HONKALA, 1990). According to the same authors, even where it occurs naturally, it is not considered as a great commercial importance species and there is little information about its growth. According to Moore et al. (2015), P. glabra's wood is not resistant to decay and insect attack.

The P. glabra wood density is $0.443 \mathrm{~g} \mathrm{~cm}^{-3}$ in the region of origin (KOSSUTH; MICHAEL, 1991) and $0.480 \mathrm{~g} \mathrm{~cm}^{-3}$ in trees at 21 years of age grown in Rio Negro, state of Paraná, Brazil (IWAKIRI; KEINERT JR., 1990). The shear strength was greater than that observed for P. taeda and Pseudotsuga meenziesii (KOSSUTH; MICHAEL, 1991). Still according to Iwakiri and Keinert Jr. (1990), despite a relatively old study and with possibly outdated industrial processes, they reported that $P$. glabra is one of the potentially viable species for the production of waferboards, although it resulted in panels with higher water absorption.

From the silvicultural perspective, there are interesting differences between the species of Pinus traditionally cultivated in Brazil and P. glabra. In its natural habitat, $P$. glabra is associated with hardwood species (Quercus ssp. Nyssa sylvatica Marsh., Liquidambar styraciflua L., among others) (BULER et al., 2007), mainly due to its bigger tolerance to shading in relation to $P$. taeda and $P$. elliottii. Because of this ecological feature, $P$. glabra sprouts survive longer in a shaded environment, resulting in firmer knots and better-quality wood for solid end-uses.

The aim of the present study was to evaluate the development of different dendrometric characteristics of provenances of $P$. glabra grown in the highlands of south Brazil during 24 years of growth.

\section{MATERIAL AND METHODS}

\section{Population studied}

The data were collected in an experimental stand of Pinus glabra, located in the interior of Campo Belo do Sul, state of Santa Catarina (UTM 22J 515.760 and 6.905.830 S), $960 \mathrm{~m}$ above sea level, implanted in March 1992 , with spacing of $1.6 \mathrm{~m} \times 2.5 \mathrm{~m}\left(2,500\right.$ trees ha- $\left.{ }^{-1}\right)$ with approximately $3,000 \mathrm{~m}^{2}$ of total area. The control of leafcutter ants and weed competition were carried out whenever necessary. When the trees reached $4 \mathrm{~m}$ total height, a pruning up to $2.5 \mathrm{~m}$ was performed.

The seedlings were produced with genetic material from five different sites in the southern United States, provided by Prof. Daniel Houston, Ph.D., of Ohio University (Table 1). The seeds of the trees of each origin were mixed to represent the place of origin.

Table 1. Provenances of P. glabra and the respective amount of trees from which seeds were collected in order to represent their provenance, and the number of replications within the test (plots with 10 individuals).

Tabela 1. Procedências de $P$. glabra em ordem alfabética do estado, a respectiva quantidade de árvores das quais as sementes foram coletadas para representar as procedências, e o número de repetições presentes no teste (parcelas com 10 indivíduos).

\begin{tabular}{clcc}
\hline Code & Description & $\mathbf{n}^{\mathbf{0}}$ of trees & $\mathbf{n}^{\mathbf{0}}$ of replicates \\
\hline F-LC & Florida - Leon County Tallahassee & 3 & 3 \\
G-D & Georgia - Decatur & 4 & 8 \\
L-BP & Lousiana - Beauregard Parish & 5 & 14 \\
L-BR & Lousiana - Baton Rouge & 5 & 7 \\
L-LP & Lousiana - Livingston Parish & 15 & 9 \\
\hline
\end{tabular}

The experimental design was completely randomized with a minimum of 3 and a maximum of 14 replications per origin, depending on the number of seedlings available (unbalanced data). Each repetition was consisted of 10 plants. A total of 410 individuals were measured $\left(1,640 \mathrm{~m}^{2}\right)$. A double border, not measured, was installed around the whole experiment with the remaining seedlings, without control of the origin.

At the age of 12 years, a selective thinning from below was performed, with a $30 \%$ removal of the number of trees considering the distribution of the remaining trees and without control of the provenances, making it impossible to analyze them individually since them. 


\section{Collection of data}

The diameter at breast height $(\mathrm{dbh}, 1.3 \mathrm{~m})$ and total height $(\mathrm{h})$ of all subjects were measured from the age of 3 years with a diametrical tape and a Vertex ${ }^{\mathrm{TM}}$ hypsometer, respectively. Then, annual measurements were made up to 14 years of age.

At 24 years of age, a forest inventory was carried out using the Prodan method, disregarding the different origins, with the installation of 11 sample units, where the dbh and total height of the trees were measured. Considering the sum of the areas of each sampling point and the total area of the population, a sample intensity of $20 \%$ (finite population) was reached. At the same age, 21 trees were selected and harvested for scaling (dbh: 15$44 \mathrm{~cm}$; h: 22-31 m), 3-5 trees per diameter class, comprising the amplitude of \pm 2.5 standard deviations around the mean $\mathrm{dbh}$, and 1 individual above this limit. The Smalian scaling method was regarded at heights $0.1,0.5,1.0$, $1.3,1.5$ and $2.0 \mathrm{~m}$, then at $2 \mathrm{~m}$ intervals until three apex.

Among the harvested trees, 15 were selected $(\mathrm{dbh}: 15-41 \mathrm{~cm})$ for stem analysis and reconstruction of the current annual increment. Cross discs were collected at $0.1,1.3,2,4,6,8$ and $10 \mathrm{~m}$ high. Based on stem analysis data, it was possible to complement the study of annual increment in diameter in the years in which there was no field measurement. In addition, it was possible to analyze the growth of the basal $10 \mathrm{~m}$ of the tree, region of major interest and commercial value. The study was limited to $10 \mathrm{~m}$ basal because at this age and height, trees had a diameter of $20 \mathrm{~cm}$, practically the limit of commercial use for solid and nobler end-uses.

\section{Data analysis}

The different origins were compared in terms of total height at 5 years and dbh at 12 years of age. The height analysis at 5 years was carried out with the purpose of characterizing the initial growth, considering that at this stage the potential for height development is fundamental for the establishment of commercial plantations. The analysis considered the fact that there was a different amount of repetitions for each source (unbalanced data) and, therefore, for the calculations of the analysis of variance, the sum of squares 'type III' was used.

After the equality of variances (Bartlett's test), residues independence (Durbin-Watson's test) and normality (Shapiro Wilk's test) were confirmed, data were submitted to analysis of variance and, if considerable differences were detected, Tukey's test (minimum level of significance $=0.05$ ) was used to distinguish the means, all performed in the $\mathrm{R}$ program (CORE TEAM, 2016).

The data processing of the inventory at the age of 24 years was carried out without individualizing the provenances and thus allowing the analysis of the average growth potential for the species in the southern plateau of Brazil.

In order to estimate the volume and shape of the individuals' stem from operationally measurable variables ( $\mathrm{dbh}$ and $\mathrm{h}$ ), several models were evaluated. The models were fitted by the ordinary least squares method. The quality of the fitting was evaluated using: the adjusted coefficient of determination $\left(\mathrm{R}^{2}{ }_{\mathrm{aj}}\right)$, standard error of the estimate $\left(\mathrm{S}_{\mathrm{yx}}\right)$ and graphical analysis of residues. The adjustment of the models was done with the aid of the program R (R CORE TEAM, 2016). Table 2 shows the volumetric equation selected because of the best fit. And it was used in the present study to quantify production. In spite of not being used in this work, due to the novelty of the analysis of the species, Table 2 also shows the best fit tapering equation.

Paired data $\mathrm{d}_{100} \mathrm{x}$ age were used to adjust the Chapman-Richards' growth model (Table 2) and, from the cumulative growth curve, the current and mean annual growth curves were obtained over the analysis period.

Table 2. Fitted equations for volume (Schumacher-Hall), taper (Schöpfer) and dominant diameter growth (Chapman-Richards) of 24-years old P. glabra trees in south Brazil, as well as the statistics of fitting quality and precision.

Tabela 2. Equações ajustadas para estimar o volume (Schumacher-Hall) e o afilamento (Schöpfer) de P. glabra com 24 anos de idade no sul do Brasil e o crescimento (Chapman-Richards) em diâmetro dominante, acompanhado de suas respectivas estatísticas de qualidade de ajuste e precisão.

FLORESTA, Curitiba, PR, v. 49, n. 2, p. 277-286, abr/jun 2019. 


\begin{tabular}{|c|c|c|c|c|c|}
\hline Heading & Adjusted equation & $\mathbf{R}^{2}$ aj. & $\mathbf{S}_{\mathbf{y x}}$ & $\mathrm{S}_{\mathrm{yx}}(\%)$ & FM \\
\hline $\begin{array}{c}\text { Schumacher-Hall } \\
\text { (1933) }\end{array}$ & $\begin{array}{l}\ln (v)=-10,594 \\
+1,769 \ln (\text { dap }) \\
+1,360 \ln (h)\end{array}$ & 0.992 & $0.0471 \mathrm{~m}^{3}$ & 5.8 & 1.002 \\
\hline $\begin{array}{l}\text { Schöpfer } \\
\text { (1966) }\end{array}$ & $\begin{array}{l}\frac{d_{i}}{d a p}=+1,11888 \\
-2,73375\left(\frac{h_{i}}{h}\right)^{2} \\
+12,99398\left(\frac{h_{i}}{h}\right)^{2} \\
-31,58709\left(\frac{h_{i}}{h}\right)^{3} \\
+32,92579\left(\frac{h_{i}}{h}\right)^{4} \\
-12,74595\left(\frac{h_{i}}{h}\right)^{5}\end{array}$ & 0.959 & $2.0 \mathrm{~cm}$ & 9.7 & - \\
\hline $\begin{array}{l}\text { Chapman-Richards } \\
\text { (1959) }\end{array}$ & $d_{100}=35,117 *\left(1-e^{-0,214 * I}\right)^{2,836}$ & & $3.6 \mathrm{~cm}$ & 15.6 & \\
\hline
\end{tabular}

In which, ln: natural logarithm; v: individual volume in $\mathrm{m}^{3} ; \mathrm{dbh}$ : diameter at breast height in $\mathrm{cm}$; $\mathrm{h}$ : total height in $\mathrm{m} ; \mathrm{d}_{\mathrm{i}}:$ stem diameter in $\mathrm{cm}$ at height $\mathrm{h}_{\mathrm{i}} ; \mathrm{d}_{100}$ : dominant diameter; $e$ : exponential; $\mathrm{I}$ : Age; $\mathrm{R}_{\text {aj }}^{2}$ : adjusted coefficient of determination; $\mathrm{S}_{\mathrm{yx}}$ : standard error of the estimate in absolute and relative terms; FM: Meyer logarithmic discrepancy correction factor. All parameters of the presented models were obtained with $p<0.01$.

The study of the growth in $\mathrm{d}_{100}$ was performed using information of the 16 trees of greater diameter in all the experimental area, disregarding the provenances. Despite this, it should be noted that all provenances were represented. In order to complement the period in which there were no field measurements, stem analysis data from the 8 largest trees were used, with dbh similar to the dominant ones at 24 years, considering also a mean bark thickness of $3.6 \mathrm{~mm}$ (radius) for the obtaining of $\mathrm{d}_{100}$ with bark over this period.

Figure 1 shows the residual graphs for the adjusted equations shown in Table 2.
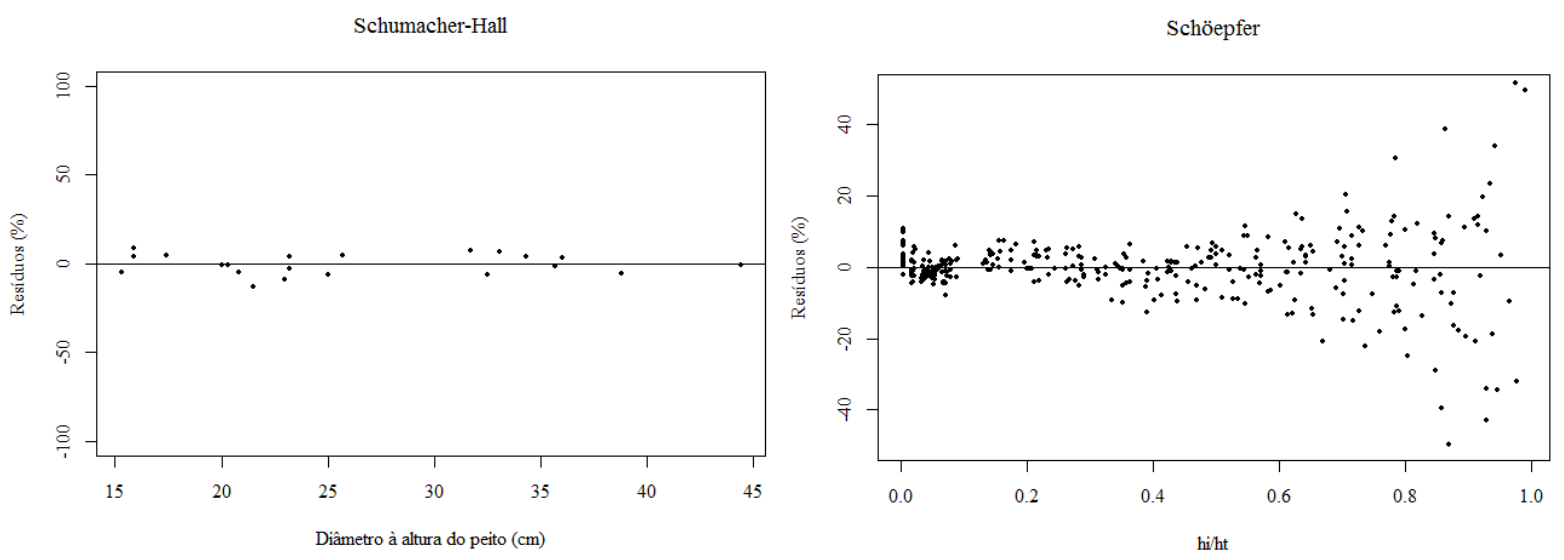

Figure 1. Graphical analysis for the Schumacher-Hall (volume) and Schöpfer (taper) equations, fitted for 24years-old $P$. glabra trees grown in the highlands of south Brazil.

Figura 1. Análise gráfica de resíduos para as equações de Schumacher-Hall (volume) e de Schöpfer (afilamento) ajustadas para $P$. glabra com 24 anos no planalto sul do Brasil.

Basal area information in the respective forest inventory ages was also used to construct a cumulative growth curve. In this case, there was no fitting of growth model.

From stem analysis, it was detected that the formation of the annual growth ring corresponding to $24^{\text {th }}$ year was incomplete. Therefore, the analyzes performed from these data considered only the information recorded up to $23^{\text {rd }}$ year of age of the trees. 


\section{RESULTS}

\section{Provenances analysis}

At 5 years of age, a total of 367 individuals were alive, representing an average mortality of $10 \%$, distributed evenly among provenances.

The first analysis related to the growth refers to the total height of the trees at 5 years of age, allowing the evaluation of the initial growth rhythm of the different provenances. Due to the non-normal height at 5 years, it was necessary to use the Box-Cox transformation.

The average height by origin at 5 years of age and the mean diameter (dbh) by provenance at 12 years are shown in Figure 2.

After the equality of variances (Bartlett, $p=0.10$ ) was confirmed, the residues' independences (DurbinWatson, $p=0.33$ ), data (Shapiro-Wilk, $p=0.34$ ) and residues (Shapiro-Wilk, $p=0.51$ ) normality, a variance analysis was carried out, detecting significant differences in height between the evaluated provenances $(p<0.01)$ : provenances L-LP, F-LC, G-D and L-BR were superior and similar to each other, with an average increase in height of more than $1.4 \mathrm{~m}_{\text {year }}{ }^{-1}$. The L-BP origin was inferior only to L-LP and F-LC (Figure 2). Although significant differences were detected. In average terms it is emphasized that the differences do not present greater practical relevance, being approximately $1 \mathrm{~m}$ between extremes (5.5-6.6 $\mathrm{m})$.
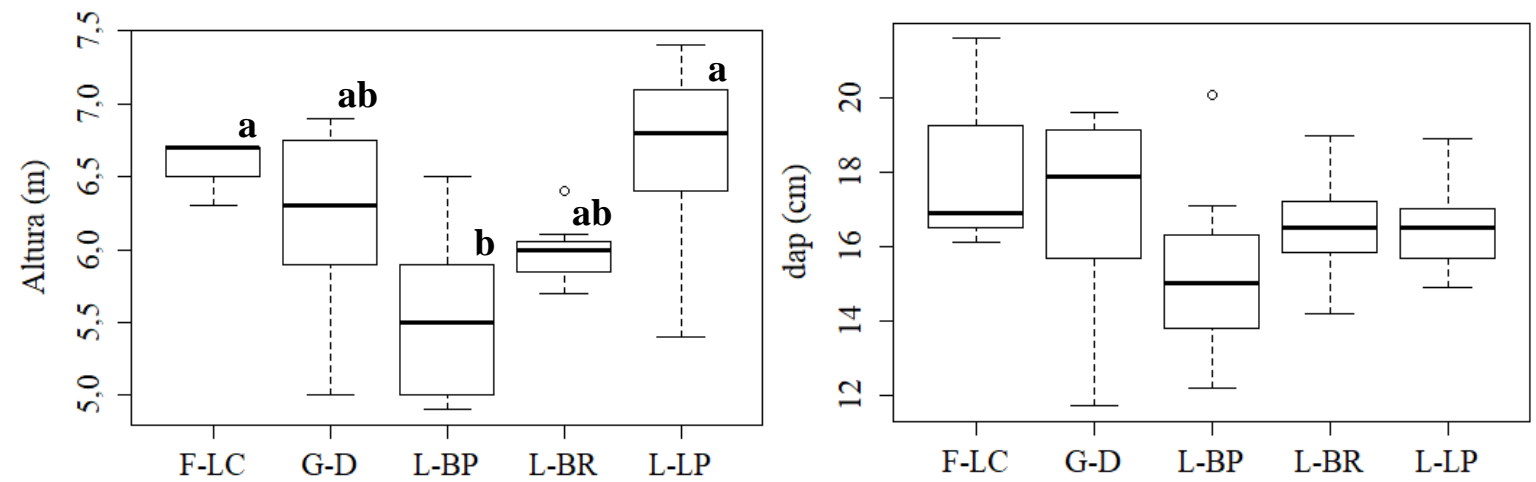

Figure 2. Total height at age 5 years $(n=41)$ and diameter at breast height $(d b h)$ at age 12 years $(n=41)$ for the different provenances of $P$. glabra grown in the highlands of south Brazil.

Figura 2. Altura total aos 5 anos de idade $(n=41)$ e diâmetro à altura do peito (dap) aos 12 anos de idade $(n=41)$ para as diferentes procedências de P. glabra cultivadas no planalto sul do Brasil.

In terms of accumulated dbh up to 12 years of age, there was small variation among the provenances (15$18 \mathrm{~cm}$, Figure 2). The variance equality (Bartlett, $p=0.28$ ), the residues' independence (Durbin-Watson, $p=0.68$ ), normality of the data (Shapiro-Wilk, $p=0.34$ ) and the residues (Shapiro-Wilk, $p=0.94$ ), the analysis of variance revealed no significant differences $(p<0.12)$. It is also observed in Figure 2 that the F-LC provenance presented plots with average dbh higher than $20 \mathrm{~cm}$.

Despite of the low variation between averages of the provenances, both for height and diameter, a considerable variability within the same provenance can be observed in Figure 2. This indicates the presence of potential for selection and establishment of programs of genetic improvement.

\section{Production potential at age 24 years}

The volume equation fitted with data collected in the present study and already presented in the Material and Methods, together with the forest inventory, made it possible to obtain the estimate of the volumetric stock with bark of the trees at 24 years of age. A summary of the stand characteristics of $P$. glabra is given in Table 3 . It was decided by the joint analysis of all the provenances due to the small differentiation of them, mainly in dbh, as shown in Figure 2, and thus to evaluate more robustly the productive potential of the species for the formation of commercial stands in the southern plateau of Brazil.

Table 3. Dendrometric data at age 24 years for the P. glabra stand, their respective lower (L.I.) and upper (L.S.) limits with $95 \%$ of probability, and the sampling estimation error in percentage. 
Tabela 3. Dados dendrométricos aos 24 anos de idade do povoamento de P. glabra, com os respectivos limites inferior (L.I.) e superior (L.S.) com 95\% de probabilidade de acerto, e o erro amostral da estimativa em porcentagem.

\begin{tabular}{cccccc}
\hline Variable & unit & L.I. & Average & L.S. & Sample error $(\%)$ \\
\hline $\mathrm{d}_{\mathrm{g}}$ & $(\mathrm{cm})$ & 24 & 25.7 & 27 & 6.9 \\
$\mathrm{~h}$ & $(\mathrm{~m})$ & 26 & 26.5 & 27 & 1.8 \\
$\mathrm{~V}_{\mathrm{i}}$ & $\left(\mathrm{m}^{3}\right)$ & 0.6 & 0.698 & 0.8 & 14.5 \\
$\mathrm{~N}$ & $\left(\mathrm{tree} \mathrm{ha}^{-1}\right)$ & 884 & 1,088 & 1,293 & 18.8 \\
$\mathrm{G}$ & $\left(\mathrm{m}^{2} \mathrm{ha}^{-1}\right)$ & 47 & 56.0 & 65 & 16.7 \\
$\mathrm{~V}$ & $\left(\mathrm{~m}^{3} \mathrm{ha}^{-1}\right)$ & 619 & 745.5 & 873 & 17.0 \\
\hline
\end{tabular}

In which, $\mathrm{d}_{\mathrm{g}}$ : mean square diameter; h: total height; $\mathrm{v}_{\mathrm{i}}$ : mean individual volume; $\mathrm{N}$ : number of trees; G: basal area; V: total volume per hectare.

It can be seen in Table 3 that the forest inventory by the Prodan method, despite a high sample intensity $(20 \%)$, resulted in estimates with an acceptable sampling error $(<10 \%)$ only for $\mathrm{d}_{\mathrm{g}}$ and $\mathrm{h}$ characteristics. The estimates of individual volume $\left(\mathrm{v}_{\mathrm{i}}\right)$ and stand variables (N, G and $\mathrm{V}$ ) were obtained with errors up to $18.8 \%$.

Volumetric stocks with bark at 24 years of age totaled $745.5 \mathrm{~m}^{3} \mathrm{ha}^{-1}$, equivalent to an average increase of $31.1 \mathrm{~m}^{3} \mathrm{ha}^{-1}$ year ${ }^{-1}$, disregarding the volume harvested at 12 years of age.

The upper limit of the confidence interval for the variable $d_{g}$ was $27 \mathrm{~cm}$ (Table 3), however, among the individual observations in the sample units, a maximum value of $42.9 \mathrm{~cm}$ was detected, reinforcing the superior growth potential of some individuals. In average terms for a stand composed of all tested provenances, the values presented in Table 3 are more representative.

An evaluation of the growth potential in diameter can be obtained from the growth curve of dominant trees (100 trees of greater $\mathrm{dbh} \mathrm{ha}^{-1}$, Figure 3 -A). It is noted that a dominant diameter $\left(\mathrm{d}_{100}\right)$ of $30 \mathrm{~cm}$ can be obtained at 15 years of age, and that these same dominant individuals reached current increments greater than $3 \mathrm{~cm}_{\text {year }}^{-1}$. Even after 20 years of age, dominant individuals maintained average increments in diameter greater than $1 \mathrm{~cm}$ year $^{-1}$ (Figure 3-B).

The evolution over the years of the basal area (Figure 3-C) indicates an occupation of the productive space of approximately $40 \mathrm{~m}^{2} \mathrm{ha}^{-1}$ at 10 years of age. Although there is no available knowledge about the management of stands of $P$. glabra in the conditions of study, it can be stated that this would have been a good age to carry out a first thinning in the case of a commercial stand managed for multiple uses of wood.

With respect to the performed stem analysis, it is observed in Figure 3-D that the rings of larger growths $(>1.0 \mathrm{~cm})$ are restricted to the central $6 \mathrm{~cm}$ of the radial profile. This higher growth is similar in all the studied heights $(\leq 10 \mathrm{~m})$, characteristic of the formation of juvenile wood, near the region of the active crown. It is also observed that the average sharpness of the trees is relatively abrupt in the first $6 \mathrm{~m}$ of height, stabilizing up to $8 \mathrm{~m}$, when it sharpens again abruptly.

\section{DISCUSSION}

Mortality observed in the present study was lower than that reported by Shimizu and Higa (1980) for other provenances of $P$. glabra grown in Irati, state of Paraná, which was up to $40 \%$ near 4 years of age. In the same work, heights between 1.6-1.8 $\mathrm{m}$ are also reported, they were substantially lower than observed in the present study, and may indicate, in addition to differences in the genetic material evaluated, responses to site particularities.

Kossuth and Michael (1991), evaluating native stands of $P$. glabra in the southeastern of the United States, reported dbh values at 15 and 30 years of 20 and $30 \mathrm{~cm}$, respectively. Another analysis of poor and excellent site growth for $P$. glabra in the US indicated dbh of $17-31 \mathrm{~cm}$ with $14-22 \mathrm{~m}$ height at 30 years of age, respectively (BURNS; HONKALA, 1990). Despite different ages from those evaluated in this study, it can be stated that the growth rate of $P$. glabra in southern Brazil is similar to that observed in the region of natural occurrence of the species.

Elesbão and Schneider (2011) reported average values for dbh of $24 \mathrm{~cm}$ and height of $24 \mathrm{~m}$ at 17 years of unthinned stands of $P$. taeda in southern Brazil. Values similar to those observed in the present study at 24 years of age, indicating growth superiority of $P$. taeda in relation to $P$. glabra.

However, the observed productivity $\left(31 \mathrm{~m}^{3} \mathrm{ha}^{-1} \mathrm{year}^{-1}\right)$ proves the productive potential of the species, being comparable to that reported for $P$. taeda, between 25-44 $\mathrm{m}^{3} \mathrm{ha}^{-1}$ (ABRAF, 2013; ACR, 2016), although there are occasional reports of more than $50 \mathrm{~m}^{3} \mathrm{ha}^{-1}$ year ${ }^{-1}$ for the same species (MAINARDI et al., 1996; NASCIMENTO et al., 2015). 
It should be noted, however, that there was an attack of Sirex woodwasp from the $12^{\text {th }}$ year of age on the evaluated stand, possibly due to the high competition among the individuals. Besides a phytosanitary concern, this fact implied in the accelerated mortality of some individuals and, consequently, reduction of the volumetric production described in the previous paragraph. This event also prevented a fair comparison between the provenances at the age of 24 of settlement, since individuals whose neighbors died were obviously favored.

At the Experimental Station of Rio Negro-PR (UFPR), a stand of P. glabra established in 1967, also at 24 years of age, had an average dbh of dominant trees of $27-35 \mathrm{~cm}$, an average total height of $25 \mathrm{~m}$, basal area of $69 \mathrm{~m}^{2} \mathrm{ha}^{-1}$ (unpublished data). Therefore, values similar to those reported in the present study are pointed, indicating the species' plasticity in different edaphoclimatic conditions, in this case, distant $250 \mathrm{~km}$.
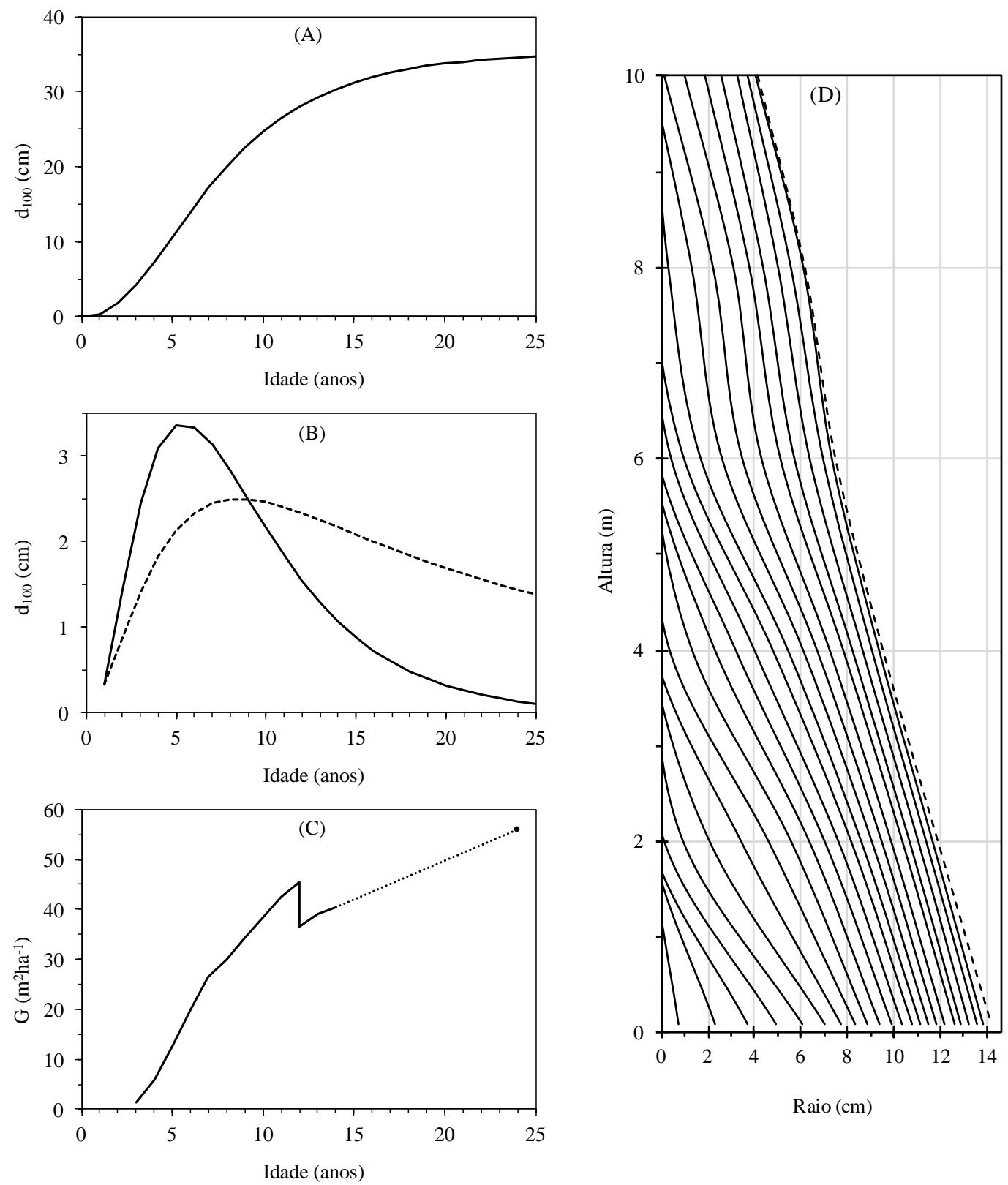

Raio (cm)

Figure 3. (A) cumulative growth in diameter at breast height for the dominant trees $\left(\mathrm{d}_{100}\right)$; (B) current annual increment (full line) and mean annual increment (dashed line) for the $\mathrm{d}_{100}$; (C) cumulative basal area growth, where the dashed line represents the period on which no inventory was carried out; (D) radial and height growth profile obtained by complete stem analysis where the growth ring widths and the 
bark width (dashed line) are given, measured at different heights for $P$. glabra grown in the highlands of southern Brazil.

Figura 3. (A) crescimento acumulado em diâmetro à altura do peito com casca das árvores dominantes $\left(\mathrm{d}_{100}\right)$; $(\mathrm{B})$ incremento corrente anual (linha cheia) e incremento médio anual (linha tracejada) para $\mathrm{d}_{100}$; (C) crescimento acumulado em área basal, onde a linha pontilhada representa o período no qual não foi realizado inventário florestal; (D) perfil de crescimento médio radial e em altura obtido por meio de análise de tronco apresentando a espessura dos anéis de crescimento e da casca (linha tracejada) mensurados nas diferentes alturas para P. glabra cultivado no planalto sul do Brasil.

Considering the good quantified growth in the present study, and the silvicultural advantages of $P$. glabra, compared with $P$. taeda, with higher shade tolerance and, consequently, higher quality wood production with firm knots due to longer survival time of the branches, it is inferred that $P$. glabra could be of interest for production schemes for multiple uses of wood. Such regimes necessarily require the use of thinning during the production cycle. Thus, the dendrometric characterization presented should be evaluated with reserve, since it is the result of a single thinning, relatively late and of low intensity. In other words, the actual growth potential in diameter of the species is probably even greater than that described herein.

Finally, additional studies on wood quality of P. glabra are recommended. This is a key factor, together with the information presented in the present study, for recommending the commercial use of this species.

\section{CONCLUSIONS}

From the results obtained in the present study, we conclude that:

- All provenances proved to be suitable for cultivation in the study conditions, with similar initial growth in height between the L-LP, F-LC, G-D, and L-BR provenances, differentiating only the L-BP provenance from the first two. In spite of this, all provenances showed good initial growth, above $1 \mathrm{~m}_{\text {year }}{ }^{-1}$ in the first 5 years, indicating good adaptation to the edaphoclimatic conditions evaluated.

- The commercial use potential of Pinus glabra in southern Brazil plateaus was proved, being, therefore, an interesting alternative to commonly used species. Productivities above $30 \mathrm{~m}^{3} \mathrm{ha}^{-1}$ year ${ }^{-1}$ at 24 years of age, as well as the production of dominant individuals with $30 \mathrm{~cm}$ of diameter at 15 years of age can be expected.

\section{ACKNOWLEDGMENTS}

The authors are grateful to the company Florestal Gateados Ltda. for support during all phases of the study. To Prof. Rudi Arno Seitz (in memoriam), for the establishment, custody and monitoring of the experiment during the initial phase of the experiment.

\section{REFERENCES}

ABRAF - Associação Brasileira de Produtores de Florestas Plantas. Anuário Estatístisco 2013, ano base 2012. 2013. 142 p.

ACR - Associação Catarinense de Empresas Florestais. Anuário Estatístico de base florestal para o estado de Santa Catarina 2016, ano base 2015. 2016. 105 p.

BULER, J. J.; MOORE, F. R.; WOLTMANN, S. A multi-scale examination of stopover habitat use by birds. Ecology, Washington, v. 88, n. 7, p. 1789 - 1802, 2007.

BURNS, R. M; HONKALA B. H. Silvics of Forest Trees of the United States. U.S. Department of Agriculture, Forest Service, Washington, v. 1, 1990, 877 p.

CODER, K. D. Native trees of Georgia. Warnell School of Forestry \& Natural Resources, n. 9, 2016. 6 p.

ELESBÃO, L. E. G.; SCHNEIDER, P. R. Produção do Pinus taeda em povoamento desbastado na região dos Campos de Cima da Serra, Rio Grande do Sul. Ciência Florestal, v. 21, n. 1, p.119 - 124, 2011.

GULDIN, J. M. Silvicultural considerations in managing southern pine stands in the context of southern pine beetle. USDA Forest Service, Southern Research Station, Hot Springs, AR 71902. 2011, 36 p.

IBÁ - Indústria Brasileira de Árvores. Relatório 2017. Brasília. 2017, 80 p.

IWAKIRI, S.; KEINERT JR., S. Utilização de diferentes espécies do gênero Pinus para produção de painéis “waferboard”. IPEF, n. 43/44, p. 65-69, 1990. 
KOSSUTH, S. V.; MICHAEL, J. L. Pinus glabra Walt. In: Silvics of North America, I. Conifers. Agric. Handb, 654, Washington, U.S., Department of Agriculture, p. 355 - 358, 1991.

LITTLE Jr. E. L. Atlas of United States trees; v. 1. Conifers and important hardwoods. Washington, DC. USDA, Forest Service, 1971. (Miscelaneous Publication, 1146).

MAINARDI, G. L.; SCHNEIDER, P. R.; FINGER, C. A. G. Produção de Pinus taeda L. na região de Cambará do Sul, RS. Ciência Florestal, v. 6, n. 1, p. 39 - 52, 1996.

MIROV, N.T. The genus Pinus. New York, The Ronald Press, 1967. 602 p.

MOORE, R. K.; SMAGLICK, E. A.; LEITCH, M.; MANN, D. The effect of polarity of extractives on the durability of wood. Proceedings of the USDA-FS Forest Products Laboratory, Madison. 2015. 4 p.

NASCIMENTO, F. A. F.; DIAS, A. N.; FIGUEIREDO FILHO, A.; MIRANDA, G. M.; ARCE, J. E. Sistema de crescimento e produção para povoamentos de Pinus taeda na região norte de Santa Catarina. Cerne, v. 21, n. 2, p. $235-242,2015$.

R CORE TEAM (2016). R: A language and environment for statistical computing. R Foundation for Statistical Computing, Vienna, Austria. URL https://www.R-project.org/.

SHIMIZU, J. Y.; HIGA, A. R. Comportamento de procedências de Pinus glabra Walt. Em relação ao P. elliottii em Irati, PR. EMBRAPA, Circular Técnica 01. 1980. 7 p.

SHIMIZU, J. Y.; SEBBENN, A. M. Espécies de Pinus na Silvicultura brasileira. In: SHIMIZU, J. Y. (Ed.) Pínus na silvicultura brasileira. EMBRAPA, Colombo. 2008, p. 17-47. 
FLORESTA, Curitiba, PR, v. 49, n. 2, p. 277-286, abr/jun 2019 Dobner Jr. M. et.al. 